\title{
STRUKTUR VEGETASI MANGROVE DI PESISIR SUMURI, TELUK BINTUNI, PAPUA BARAT
}

\section{The Vegetation Structure of Mangrove at Coastal Area of Sumuri, Bintuni Bay, West Papua}

\author{
Krisma Lekitoo*, Yunus Tambing \\ Balai Penelitian dan Pengembangan Lingkungan Hidup dan Kehutanan (BP2LHK) Manokwari \\ *Korespondensi: krisma_lekito@yahoo.co.id
}

\begin{abstract}
ABSTRAK
Data primer mangrove sangat penting dikumpulkan secara terperinci bagi penilaian ekosistem, struktur vegetasi, dan jauh lebih dari itu adalah fungsi ekologi jangka panjang lanskap. Secara terperinci data kualitatif dan kuantitatif vegetasi mangrove pada berbagai tingkatan pertumbuhan di kawasan hutan mangrove Sumuri, Teluk Bintuni belum diketahui padahal data-data tersebut sangat diperlukan untuk menilai keadaan kesehatan ekosistem dan habitat saat ini dan dapat digunakan untuk mendeteksi perubahan-perubahan lingkungan pada masa mendatang. Penelitian ini bertujuan untuk menganalisa struktur vegetasi mangrove pada tingkat pertumbuhan semai, belta, dan pohon khususnya di kawasan mangrove Kido, Sumuri, Teluk Bintuni, Papua Barat. Hasil analisa menunjukkan bahwa nilai INP Bruguiera gymnorrhiza tertinggi untuk seluruh tingkatan pertumbuhan mangrove dengan rincian semai $55.397 \%$, belta 76,649, dan pohon sebesar 88,534 \%. Bruguiera gymnorrhiza merupakan penciri utama bagi kawasan hutan mangrove Kido, Sumuri, Teluk Bintuni. Faktor utama pendukung pertumbuhan Bruguiera gymnorrhiza untuk semua tingkat pertumbuhan adalah kondisi habitat hutan mangrove Kido yang berupa lumpur dengan substrat dangkal.
\end{abstract}

Keywords: Mangrove, Nilai Penting, Ekosistem, Sumuri

\section{PENDAHULUAN}

Penelitian tentang komposisi jenis dan struktur vegetasi hutan mangrove sangat berguna dalam menggambarkan dan mendeskripsikan bentang alam (lanskap) pesisir dan proses-proses ekologi didalamnya seperti aliran energi, nutrisi, hidrologi maupun migrasi fauna. Komponen biotik utama dalam banyak kasus di kawasan hutan-hutan alam mangrove pesisir Papua sering terabaikan. Padahal keberlanjutan fungsi ekologi ekosistem ini termasuk pasokan protein hewani bagi manusia pada masa depan sangat dipengaruhi oleh kelestariannya saat ini.

Utamanya di wilayah pesisir ekosistem mangrove mendukung proses-proses ekologi dan kehidupan berbagai komponen bitotik di wilayah pesisir. Hutan mangrove sebagai tipe hutan khas yang terdapat di sepanjang pantai atau muara sungai yang dipengaruhi oleh pasang surut air laut (Nontji, 1987). Selain menyimpan karbon dan basis habitat berbagai spesies fauna teresterial, dan juga ikan, udang serta biota laut lainnya, pesisir hutan mangrove juga sering dimanfaatkan sebagai tempat mendirikan pelabuhan, transportasi, lahan tambak dan lokasi pariwisata hingga kayunya dijadikan bahan bangunan.

Struktur organisasi individu-individu tumbuhan dalam lanskap akan membetuk tegakan dan jauh lebih luas akan membentuk tipe vegetasi (Dansereau dalam Dumbois dan Ellenberg 1974). Proses-proses ekologi penting diasumsikan didukung dalam hutan pada setiap tingkatan pertumbuhan baik semai, belta hingga 
pohon. Saat ini terdapat hutan mangrove yang masih berdiri tegak dalam fragmen-fragmen hidrologi pesisir yang luas di kawasan pesisir Sumuri, Teluk Bintuni, Papua Barat. Walaupun berada dalam kondisi cukup prima, konektivitas dan proses ekologis antar fragmen yang ada saat ini harus terus dipelihara pada masa mendatang.

Vegetasi mangrove sangat memegang peran penting dalam keseimbangan ekosistem di daratan. Sedikit saja fragmentasi dipastikan akan mengganggu proses-proses ekologi yang spesifk dan dominan pada bagian teresterial hutan. Indeks nilai penting sebagai parameter kuantitatif yang dapat dipakai untuk menyatakan dominan (tingkat penguasaan) suatu jenis tumbuhan berkayu dalam suatu komunitas tumbuhan atau seberapa besar peran jenis tersebut secara ekologi dalam suatu komunitas hutan (Soegianto, 1994) perlu untuk dipelajari pada pesisir Sumuri yang sangat mendapat tekanan akibat berbagai aktivitas industri, perkebunan, dan ekstraksi kayu. Oleh karena itu penelitian tentang komposisi jenis dan struktur vegetasi mangrove sangat berguna dalam menggambarkan dan mendeskripsikan lanskap saat ini.

\section{METODE}

\section{Koleksi Data}

Lokasi koleksi data berada pada kawasan hutan mangrove Kido, Distrik Sumuri, Teluk Bintuni, Papua Barat. Pengamatan dan koleksi data tumbuhan berkayu pada hutan mangrove dilakukan pada jalur dengan petak berlanjut (continuous strip sampling) yang dibuat memotong kontur untuk mengetahui potensi dan komposisi tegakan. Panjang jalur $\pm 100 \mathrm{~m}$, jarak antar jalur $20 \mathrm{~m}$ dengan petak-petak pengamatan menurut Bengen (2001) yaitu: pohon $10 \times 10 \mathrm{~m}$, pancang (belta) $5 \times 5 \mathrm{~m}$, dan semai $2 \times 2 \mathrm{~m}$.

Data hasil penelitian terkoleksi selanjutnya dianalisa secara deskriptif tabulasi berdasarkan aspek dan tujuan penelitian. Penyajian data juga dalam bentuk gambar, foto dan tabel. Data pengukuran diameter, ditabulasi dan diolah serta dianalisa berdasarkan nilai Indeks Nilai Penting (INP) masing-masing jenis. Langkah perhitungan INP adalah sebagai berikut :
1) Nilai Kerapatan Jenis $(K)=$ $\frac{\text { Jumlah individu jenis } i}{\text { Luas seluruh petak contoh }}$

2) Nilai Kerapatan Relatif Jenis (KR) = $\frac{\text { Kerapatan jenis } i}{\text { Total nilai Kerapatan seluruh jenis }} \times 100 \%$

3) Nilai Frekuensi Jenis $(\mathrm{F})=$ Jumlah petak contoh yangberisi jenis $i$ Jumlah seluruh petak contoh

4) Nilai Frekuensi Relatif $(\mathrm{FR})=$ $\frac{\text { Frekuensi jenis } i}{\text { Total nilai Frekuensi seluruh jenis }} \times 100 \%$

5) Nilai Dominansi Jenis (D) = Luas bidang dasar jenis $i$ Luas seluruh petak contoh

6) Nilai Dominansi Relatif $(D R)=$ $\frac{\text { Dominansi jenis } i}{\text { Dominansi seluruh jenis }} \times 100 \%$

7) Nilai Indeks Nilai Penting $($ INP $)=$

$$
\mathrm{KR}+\mathrm{FR}+\mathrm{DR}
$$

Data jenis dan jumlah jenis yang dijumpai selanjutnya digunakan untuk menghitung Indeks Keanekaragaman Jenis dengan Indeks ShannonWiener (Ludwig \& Reynolds, 1988) :

$$
H^{\prime}=-\sum p_{i} \ln p_{i}=\sum \frac{n_{i}}{N} \ln \frac{n_{i}}{N}
$$

$$
\begin{array}{ll}
\text { Dimana: } & \\
\mathrm{H}^{\prime} & =\text { Indeks Shannon-Wiener } \\
\mathrm{pi} & =\text { proporsi jenis ke-i } \\
\mathrm{ni} & =\text { jumlah jenis ke-i } \\
\mathrm{N} & =\text { jumlah total individu } \\
\mathrm{Ln} & =\text { logaritma nature }
\end{array}
$$

Kriteria indeks keanekaragaman berdasarkan Shannon-Wiener (Krebs, 1985) adalah: $\quad H^{\prime}<1$ : Keanekaragaman rendah, penyebaran jumlah individu tiap spesies rendah dan kestabilan komunitas rendah; $1>\mathrm{H}^{\prime}<3$ : Keanekaragaman sedang, penyebaran jumlah individu tiap spesies sedang dan kestabilan komunitas sedang; $\mathrm{H}^{\prime}>3$ : Keanekaragaman tinggi: penyebaran jumlah individu tiap spesies tinggi dan kestabilan komunitas tinggi. 


\section{HASIL DAN PEMBAHASAN}

\section{Temuan Jenis Mangrove}

Jenis vegetasi dalam ekosistem ini khususnya di kawasan hutan mangrove Kido, Distrik Sumuri, Teluk Bintuni, telah dideterminasi dan didokumentasi dengan baik. Hasil identifikasi jenis-jenis mangrove di kawasan hutan mangrove Kido adalah 15 jenis yang tergolong dalam delapan famili. Seluruhnya jenis dari semua tingkat pertumbuhan didominasi oleh famili Rhizophoraceae.

\section{Analisa Struktur Vegetasi}

\section{Tingkat Semai}

Diidentifikasi total 11 jenis tumbuhan berkayu pada tingkat semai di kawasan hutan mangrove Kido. Dari empat famili yang ditemukan, Rhizophoraceae memiliki jumlah jenis semai terbanyak yaitu Bruguiera gymnorrhiza, Rhizophora stylosa, R. apiculata, $B$. sexangula, Ceriops tagal dan $R$. mucronata.

Semai dengan INP tertinggi di kawasan hutan mangrove Kido adalah Bruguiera gymnorrhiza (55.397\%). Dengan INP 53.12\%, Rhizophora stylosa menempati urutan kedua setelah B. gymnorrhiza, sedangkan urutan ketiga adalah $R$. apiculate $(22.711 \%)$. Jenis tumbuhan berkayu mangrove lainnya seperti $R$. apiculata, B. sexangula, Xylocarpus granatum, Ceriops tagal, R. mucronata, Xylocarpus moluccensis, Avicennia marina dan A. alba memiliki nilai INP jauh lebih kecil pada tingkatan semai (Tabel 1).

Tiga jenis Bruguiera gymnorhiza, Rhizophora stylosa dan Rhizophora apiculata pada tigkatan pertumbuhan semai dengan nilai
INP tertinggi pada kawasan hutan mangrove Kido disebabkan oleh jumlah individu yang banyak dan penyebarannya merata. Ketiga jenis ini memiliki peran ekologis yang lebih tinggi dibandingkan jenis-jenis tumbuhan berkayu fase semai lainnya.

\section{Tingkat Belta}

Total 12 jenis tumbuhan berkayu yang tergolong dalam enam famili pada tingkat belta. Berdasarkan hasil analisa ternyata jenis Bruguiera gymnorrhiza masih memiliki INP tertinggi pada tingkat pertumbuhan belta di kawasan hutan mangrove Kido sebesar $76.649 \%$ (Tabel 2). Berbeda dengan tingkatan semai, urutan kedua jenis dengan INP tertinggi adalah Xylocarpus granatum (73.636\%) kemudian diikuti oleh jenis Rhizophora stylosa (67.718\%).

Jenis Bruguiera gymnorrhiza merupakan jenis yang memiliki INP tertinggi pada kawasan hutan mangrove Kido karena memiliki jumlah individu yang sangat banyak dan rata-rata pertumbuhan riap diameter yang sangat baik sama halnya dengan jenis yang memiliki INP tertinggi kedua Xylocarpus granatum. Sedangkan Rhizophora stylosa, jenis dengan INP tertinggi ketiga memiliki jumlah individu yang cukup banyak, penyebarannya yang cukup merata dan rata-rata pertumbuhan riap diameter yang cukup baik.

Secara ekologis, ketiga jenis ini Bruguiera gymnorrhiza, Xylocarpus granatum, dan Rhizophora stylosa memiliki peran yang lebih tinggi dibandingkan jenis-jenis tumbuhan berkayu pada fase belta lainnya.

Tabel 1. Nilai INP Sepuluh Jenis Tumbuhan Berkayu Pada Tingkat Pertumbuhan Semai di Kawasan Hutan Mangrove Kido, Sumuri, Teluk Bintuni

\begin{tabular}{clccccc}
\hline No. & \multicolumn{1}{c}{ Nama Latin } & $\begin{array}{c}\mathrm{K} \\
(\mathrm{n} / \mathrm{ha})\end{array}$ & $\begin{array}{c}\text { KR } \\
(\%)\end{array}$ & $\mathrm{F}$ & $\begin{array}{c}\text { FR } \\
(\%)\end{array}$ & $\begin{array}{c}\text { INP } \\
(\%)\end{array}$ \\
\hline 1 & Bruguiera gymnorhiza & 6052.632 & 34.848 & 0.789 & 20.549 & 55.397 \\
2 & Rhizophora stylosa & 5657.895 & 32.576 & 0.789 & 20.549 & 53.124 \\
3 & Rhizophora apiculate & 2105.263 & 12.121 & 0.368 & 9.589 & 21.711 \\
4 & Bruguiera sexangula & 1578.947 & 9.091 & 0.421 & 10.959 & 20.050 \\
5 & Xylocarpus granatum & 131.579 & 0.758 & 0.737 & 19.179 & 19.936 \\
6 & Ceriops tagal & 921.053 & 5.303 & 0.211 & 5.480 & 10.783 \\
7 & Rhizophora mucronata & 131.579 & 0.758 & 0.263 & 6.850 & 7.607 \\
8 & Xylocarpus moluccensis & 263.158 & 1.515 & 0.105 & 2.740 & 4.255 \\
9 & Avicennia marina & 263.158 & 1.515 & 0.053 & 1.370 & 2.885 \\
10 & Avicennia alba & 131.579 & 0.758 & 0.053 & 1.370 & 2.127 \\
\hline
\end{tabular}


Tabel 2 . Nilai INP Sepuluh Jenis Tumbuhan Berkayu Pada Tingkat Pertumbuhan Belta di Kawasan Hutan Mangrove Kido, Sumuri, Teluk Bintuni

\begin{tabular}{llcccc}
\hline No. & \multicolumn{1}{c}{ Nama Latin } & $\begin{array}{c}\text { KR } \\
(\%)\end{array}$ & $\begin{array}{c}\text { FR } \\
(\%)\end{array}$ & $\begin{array}{c}\text { DR } \\
(\%)\end{array}$ & $\begin{array}{c}\text { INP } \\
(\%)\end{array}$ \\
\hline 1 & Bruguiera gymnorhiza & 26,708 & 20,549 & 29,392 & 76,649 \\
2 & Xylocarpus granatum & 26,708 & 21,918 & 25,010 & 73,636 \\
3 & Rhizophora stylosa & 26,087 & 17,809 & 23,822 & 67,718 \\
4 & Bruguiera sexangula & 4,969 & 9,589 & 5,129 & 19,688 \\
5 & Rhizophora mucronata & 3,727 & 8,219 & 4,199 & 16,145 \\
6 & Rhizophora apiculata & 3,106 & 5,480 & 3,122 & 11,707 \\
7 & Xylocarpus moluccensis & 2,484 & 5,480 & 2,681 & 10,645 \\
8 & Avicennia marina & 2,484 & 2,740 & 2,424 & 7,648 \\
9 & Ceriops tagal & 1,242 & 2,740 & 1,383 & 5,365 \\
10 & Diospyros maritima & 0,621 & 1,370 & 0,992 & 2,983 \\
\hline
\end{tabular}

\section{Tingkat Pohon}

Tingkatan pertumbuhan pohon ditemukan 13 jenis tumbuhan berkayu yang tergolong dalam tujuh famili. Fantastis, Bruguiera gymnorrhiza masih merupakan jenis pohon yang memiliki INP tertinggi $(88,534 \%)$ di kawasan hutan mangrove Kido (Tabel 3). INP tertinggi dua jenis tumbuhan berkayu mangrove lainnya berturut-turut Rhizophora stylosa (86,861\%), dan Xylocarpus granatum $(48,580 \%)$.

Bruguiera gymnorrhiza, merupakan jenis yang memiliki INP tertinggi pada kawasan hutan mangrove Kido karena memiliki rata-rata pertumbuhan riap diameter yang sangat baik. Rhizophora stylosa merupakan jenis yang dominan kedua pada tingkat pertumbuhan pohon karena memiliki jumlah individu yang banyak, penyebaran yang merata dan rata-rata pertumbuhan riap diameter yang baik. Xylocarpus granatum merupakan jenis yang memiliki INP tertinggi ketiga karena memiliki jumlah individu yang cukup banyak, penyebaran yang cukup merata dan rata-rata pertumbuhan diameter yang cukup baik pada kawasan hutan mangrove Kido.

Tingkatan pohon mangrove Kido ternyata memiliki kesamaan seperti tingkatan semai dan belta, Rhizophoraceae adalah famili pada tingkat pohon yang memiliki jumlah jenis pohon terbanyak, meliputi Bruguiera gymnorrhiza, Rhizophora stylosa, Bruguiera sexangula, Rhizophora mucronata, Rhizophora apiculata dan Ceriops tagal.

Tabel 3. Nilai INP Sepuluh Jenis Tumbuhan Berkayu Pada Tingkat Pertumbuhan Pohon di Kawasan Hutan Mangrove Kido, Sumuri, Teluk Bintuni

\begin{tabular}{llllll}
\hline No. & Nama Latin & $\begin{array}{l}\text { KR } \\
(\%)\end{array}$ & $\begin{array}{l}\text { FR } \\
(\%)\end{array}$ & $\begin{array}{l}\text { DR } \\
(\%)\end{array}$ & $\begin{array}{l}\text { INP } \\
(\%)\end{array}$ \\
\hline 1 & Bruguiera gymnorhiza & 28,188 & 21,737 & 38,610 & 88,534 \\
2 & Rhizophora stylosa & 31,544 & 24,635 & 30,683 & 86,861 \\
3 & Xylocarpus granatum & 20,134 & 17,389 & 11,056 & 48,580 \\
4 & Bruguiera sexangula & 6,711 & 11,593 & 7,305 & 25,609 \\
5 & Rhizophora apiculata & 6,711 & 10,144 & 7,196 & 24,051 \\
6 & Rhizophora mucronata & 2,013 & 4,347 & 2,147 & 8,507 \\
7 & Anthocephalus chinensis & 0,671 & 1,449 & 1,093 & 3,213 \\
8 & Ficus pungens & 0,671 & 1,449 & 0,486 & 2,606 \\
9 & Xylocarpus moluccensis & 0,671 & 1,449 & 0,433 & 2,553 \\
10 & Ceriops tagal & 0,671 & 1,449 & 0,294 & 2,414 \\
\hline
\end{tabular}


Jenis Dominan Per Tingkat Pertumbuhan

Jenis Bruguiera gymnorrhiza merupakan jenis dominan pada tiga tingkatan pertumbuhan pada kawasan hutan mangrove Kido (Tabel 4). Fenomena ini disebabkan karena pada tingkatan pertumbuhan semai, belta hingga pohon, Bruguiera gymnorrhiza memiliki kemampuan tumbuh atau toleransi terhadap lingkungan habitat yang lebih baik jika dibandingkan dengan jenis-jenis tumbuhan berkayu mangrove lainnya yang merupakan jenis penyusun komunitas hutan mangrove Kido (Ewusie, 1990).

Kondisi habitat hutan mangrove Kido yang berupa lumpur dengan substrat dangkal merupakan faktor utama pendukung bagi pertumbuhan Bruguiera gymnorrhiza untuk semua tingkat pertumbuhan. Faktor inilah yang menyebabkan Bruguiera gymnorrhiza merupakan penciri utama bagi kawasan hutan mangrove Kido.

Tabel 4. Jenis Dominan Berdasarkan Tingkat Pertumbuhan di Kawasan Hutan Mangrove Kido, Sumuri, Teluk Bintuni

\begin{tabular}{cccc}
\hline No. & $\begin{array}{c}\text { Tingkat } \\
\text { Pertumbuhan }\end{array}$ & Jenis Dominan & $\begin{array}{c}\text { INP } \\
(\%)\end{array}$ \\
\hline 1. & Semai & B. gymnorrhiza & 55.397 \\
2. & Belta & B. gymnorrhiza & 76.649 \\
3. & Pohon & B. gymnorrhiza & 88.534 \\
\hline
\end{tabular}

\section{Indeks Keanekaragaman Jenis (H')}

Keanekaragaman spesies menurut Krebs (1985), dikenal dengan istilah kekayaan spesies (species richness) dan selanjutnya dikenal dengan istilah heterogenitas. Nilai indeks keanekaragaman tersebut dapat diperoleh untuk komunitas dengan kekayaan rendah dan kemerataan tinggi atau sebaliknya.

Keanekaragaman spesies yang tinggi menunjukkan bahwa suatu komunitas memiliki kompleksitas tinggi karena interaksi spesies yang terjadi dalam komunitas itu sangat tinggi. Suatu komunitas dikatakan memiliki keanekaragaman spesies yang tinggi jika komunitas tersebut disusun oleh banyak spesies. Sebaliknya suatu komunitas dikatakan memiliki keanekaragaman spesies yang rendah jika komunitas tersebut disusun oleh sedikit spesies dan jika hanya ada sedikit saja spesies yang dominan. Karena dalam suatu komunitas pada umumnya terdapat berbagai jenis tumbuhan, maka makin tua atau semakin stabil keadaan suatu komunitas, makin tinggi keanekaragaman jenis tumbuhannya (Fachrul, 2007).

Berdasarkan Tabel 5, nilai indeks keanekaragaman jenis pada kawasan hutan mangrove Kido berdasarkan Shannon-Wienner tertinggi berturut-turut pada tingkat semai dan belta (1.931), dan pohon (1.811). Berdasarkan nilai $\mathrm{H}^{\prime}$ tersebut, proses suksesi atau kestabilan komunitas pada semua tingkat pertumbuhan di kawasan hutan mangrove Kido tersebut adalah tidak stabil.

Nilai indeks keanekaragaman jenis dari tingkat semai sampai pohon yang hanya mencapai nilai 1 , menunjukan bahwa semua jenis vegetasi pada tingkat pertumbuhan semai sampai pohon tersebut mempunyai jumlah individu yang tidak sama dan memiliki kelimpahan jenis yang terdistribusi tidak sempurna atau sangat sempurna.

Berdasarkan kategori keanekaragaman jenis dalam Brower \& Zar (1990), maka untuk tingkat pertumbuhan semai, belta dan pohon pada hutan mangrove Kido memiliki keanekaragaman hayati yang rendah. Hal ini menunjukan bahwa kawasan hutan mangrove Kido termasuk dalam kategori hutan dengan keanekaragaman jenis rendah, penyebaran individu tidak merata dan kondisi kestabilan habitat rendah atau rentan terhadap kerusakan.

Tabel 5. Indeks Keanekaragaman Jenis Fase Semai, Belta, dan Pohon pada Kawasan Hutan Mangrove Kido, Sumuri, Teluk Bintuni

\begin{tabular}{lcc}
\hline \multicolumn{1}{c}{$\begin{array}{c}\text { Tingkat } \\
\text { Pertumbuhan }\end{array}$} & $\begin{array}{c}\text { Jumlah } \\
\text { Jenis }\end{array}$ & H' \\
\hline Semai & 11 & 1.931 \\
Belta & 12 & 1.931 \\
Pohon & 13 & 1.811 \\
\hline
\end{tabular}


SIMPULAN

Seluruhnya 15 jenis dari semua tingkat pertumbuhan didominasi oleh famili Rhizophoraceae. Jenis Bruguiera gymnorrhiza memiliki nilai INP tertinggi untuk seluruh tingkatan pertumbuhan mangrove yakni $55.397 \%$ semai, 76,649 belta, dan pohon sebesar 88,534 \% sehingga jenis ini dijadikan penciri utama bagi kawasan hutan mangrove Kido, Sumuri, Teluk Bintuni. Faktor utama pendukung pertumbuhan Bruguiera gymnorrhiza untuk semua tingkat pertumbuhan adalah kondisi habitat hutan mangrove Kido yang berupa lumpur dengan substrat dangkal.

\section{UCAPAN TERIMA KASIH}

Kunjungan lapangan dan akomodasi untuk mengumpulkan data dan spesimen tumbuhan dibantu sepenuhnya oleh Genting Oil Kasuri Pte.Ltd. Tentunya kerjasama ini sangat membantu kebutuhan penelitian termasuk aksesibilitas tim peneliti selama berada di lapangan. Selain itu, trima kasih juga kami sampaikan kepada Dr. Anton Sineri selaku Kepala Pusat Penelitian Lingkungan Hidup Unipa yang telah menfasilitasi penelitian ini sejak perencanaan dan persiapan awal hingga field work. Trima kasih khusus kepada Dr. Keliopas Krey yang telah mengasistensi naskah penelitian ini dan memberikan saran publikasi ilmiah.

\section{DAFTAR PUSTAKA}

Bengen, D.G. 2001. Ekosistem dan Sumberdaya Alam Pesisir dan Laut. Pusat Kajian Sumberdaya Pesisir dan Lautan, IPB, Bogor.

Brower, J.E, Zar J.H.(1990). Field and Laboratory Methods for General Ecology. Third Editon. Dubuque, Lowa: C. Brown Publisher.

Dombois M, Ellenberg H. 1974. Aims and Methods of Vegetation Ecology. John Wiley and Sons. New York, Chichester, Vriesbane, Toronto.

Ewusie, J. Y. Ekologi Tropika. 1990. ITB. Bandung.

Fachrul, M.F. 2007. Metode Sampling Bioekologi. PT. Bumi Aksara. Jakarta.

Krebs C.J. 1985. Ecological Methodology. Harper and Row Publisher Inc., New York, USA.

Ludwig, J.A., J.F. Reynolds. 1988. Statistical Ecology. A Primary on Method and computing. John Wiley and Sons, New York.

Nontji. 1987. Laut Nusantara. Penerbit Djambatan. Jakarta

Soegianto A. 1994. Ekologi Kuantitatif: Metode Analisis Populasi dan Masyarakat. Usaha Nasional SurabayaIndonesia. 